FACTA UNIVERSITATIS

Series: Economics and Organization Vol. 14, N ${ }^{\mathrm{o}}$ 1, 2017, pp. 17 - 30

DOI: $10.22190 /$ FUEO1701017S

Preliminary communication

\title{
INTERNATIONALIZATION OF RETAIL - COMPARATIVE ANALYSIS OF CROATIA AND SERBIA
}

\author{
UDC 339.162.4(497.11+497.13)
}

\author{
Svetlana Sokolov Mladenović ${ }^{1}$, Đorđe Ćuzović \\ ${ }^{1}$ University of Niš, Faculty of Economics, Niš, Serbia \\ ${ }^{2}$ Business School of Novi Sad, Niš, Serbia
}

\begin{abstract}
Globalization and integration of the world market leads to internationalization of retail and overall trade. At the turn of the century, internationalization has become a widespread retail phenomenon. Thus, it has become a permanent and inevitable process. Internationalization of trade, especially retail, covers a large number of countries, but with varying intensity. The subject of this work is the achieved level of internationalization of trade, especially retail, on the markets of the Republic of Croatia and the Republic of Serbia. Arguments for the selection of these countries are numerous. One of them is the fact that both countries originated from the former Yugoslav federation. At the same time, Croatia is the newest member of the European Union (as of $1^{\text {st }}$ July 2013), and Serbia signed the Stabilization and Association Process, and is on the way of opening membership negotiations. For these reasons, Croatian experience can serve Serbia as a landmark in the implementation of activities in the segment of trade and its internationalization. The paper aims at mapping Serbian activities in the process of further internationalization of retail.
\end{abstract}

Key words: retail, internationalization, market, Croatia, Serbia

JEL Classification: F23, O24

\section{INTRODUCTION}

Progressive globalization of the world economy has been recorded in the first years of the $21^{\text {st }}$ century. Due to these developments, along with pronounced saturation of the domestic market, a large number of retail chains are starting to carry out their activities outside the domestic market, which allows them to access new customers and new capital.

Received September 29, 2016 / Revised January 31, 2017 / Accepted February 14, 2017

Corresponding author: Svetlana Sokolov Mladenović

Faculty of Economics, University of Niš, Trg kralja Aleksandra 11, 18000 Niš, Serbia

E-mail: svetlana.sokolov@eknfak.ni.ac.rs 
Increasing globalization of markets has caused a number of processes in trade. One of them is the ever-present internationalization of trade and retail, as a business imperative of large retail chains. Thus, internationalization becomes a process of divergence and convergence in the local, regional, and global environment. What is more, reasons for internationalization are numerous and diverse, as evidenced by various papers and studies on "push" and "pull" factors. In this context, the focus is on different directions of internationalization of retail, so that some countries achieve higher and others lower degree of internationalization, measured by the number of present international trade, i.e. retail chains, and achieved sales volume. Practice shows that the main part of international retail activity takes place among Western European countries. However, due to high market saturation and the economic crisis, Eastern European countries emerged as an attractive market for international retailers, as well as countries of the former Yugoslavia, especially Slovenia and Croatia. With these facts in mind, the aim of this paper is to analyze the achieved degree of internationalization of retail on Croatian and Serbian markets. The starting hypothesis is that the Croatian market is characterized by higher degree of internationalization of retail in relation to the Serbian market. Additional hypothesis to be tested is that Croatian experience can serve Serbia in tracing the future directions of internationalization of retail.

\section{INTERNATIONALIZATION OF RETAIL IN THEORY}

Literature in the field of internationalization of trade, particularly retail, has become quite voluminous and diverse in the last 10 to 15 years. This scientific research field has attracted, and still attracts the attention of a large number of authors, mainly from developed market economies, where internationalization of trade received practical valuation. All this has led to a number of different definitions of this phenomenon, so there is no universally accepted definition of the concept of internationalization of trade. Bearing in mind different definitions of internationalization of trade and retail (Yeng \& Yazdanifard, 2015; Shulyn \& Yazdanifard, 2015), their common characteristics can be highlighted, namely: 1) internationalization of trade represents a transfer of knowledge, concepts, and business formats; 2) internationalization of trade involves doing business on two or more different international markets; 3) internationalization of trade helps overcome linguistic, cultural, social, and legal barriers to communication between the two countries; 4) internationalization of trade allows business expansion beyond national markets and finding new sources to generate profit; 5 ) internationalization is a complex process, not a series of events.

What is especially noticeable is the fact that during the nineteen-eighties and nineteennineties there was a large number of research papers dealing with internationalization of trade, which speaks about a new wave of international trade, especially retail activities. Consumer society of the nineteen-eighties made retail chains focus more on international activities, because of increasing market orientation, size of stores, as well as power of the brand. All this generated increased academic interest in the process of internationalization of trade (Alexander, 1989; Alexander 1990a; Alexander, 1990b; Williams, 1992a; Williams, 1992b). During this period, research interest focused on internationalization strategies, structure of motives, geographic expansion, market positioning, and conceptualization of internationalization process, challenges and assumptions (Sternquist, 1997; Vida \& Fairhurst 1998; Alexander \& Myers, 2000).

Conceptualization of this process opened a new research niche in a number of papers and recognized the new agenda that opened the need for a detailed analysis of various 
aspects of internationalization of trade and management of these activities. Accordingly, new research in the field of internationalization of trade at the beginning of the $21^{\text {st }}$ century focused on operational aspects of internationalization, such as market selection, entry methods, withdrawal from the market, effects, factors, and motives (Doherty, 2008; Ćuzović \& Sokolov Mladenović, 2008; Ćuzović \& Sokolov Mladenović, 2015a). In all these studies, the focus was also on internationalization of trade companies in the FMCG sector (fast-moving consumer goods), as well as in the field of fashion and luxury brands. This was certainly fueled by accelerated international activity of the world's leading retail companies, such as Wal-Mart, Carrefour, Home Depot (in FMCG sector), Zara, H\&M (the so-called fashion retailers). A common feature of all the research in the first decade of the $21^{\text {st }}$ century was quantification of research results and analysis of good case studies (Alexander \& Doherty, 2010).

Starting from 2010, research in the field of internationalization of trade has entered a new phase. Thus, Alexander and Doherty (2009) focus their theoretical and practical research on the pattern of international activity, characteristics of the expanding market, motives for internationalization, market selection, choice of entry methods, supply chain management on foreign markets, marketing and brand management, and reasons for withdrawal from the market due to a number of factors. Swoboda, Zentes, and Elsner (2009) put emphasis on motives of internationalization, internationalization strategy, market selection and entry, choice of entry methods, standardized or tailored "package deal", international performance, as well as errors in the internationalization of business. The common characteristic of this stage of research is agreement regarding international retail chains, designated as carriers of market globalization and internationalization of trade. At the same time, results of research on internationalization of trade in recent years could serve as a basis for creating the agenda for future research, as can be seen in Figure 1.

Figure 1 shows conceptualization of activities of international retail chains, which can be a platform of research agenda. Within the wider competitive market environment, Figure 1 shows three key activities: corporate domain, corporate orientation, and marketbased activities. Determinants of corporate orientation are environment and corporate characteristics, while determinants of market-based activity are market activity management and market portfolio management. Each of these determinants has two additional factors that attracted and still attract the attention of scholars and practitioners.

\section{INTERNATIONALIZATION OF RETAIL IN CROATIA}

Trade, including retail, is an important segment of the Croatian economy, as figures on the share of entrepreneurs and number of employees in trade in total GVA show. Thus, Croatian trade involves $26 \%$ of companies, with $22 \%$ of the total number of employees, and its share in GDP is around 9.3\% (http://www.hgk.hr/category/djelatnost/gosp_trgovina). In accordance with changes in the overall economic environment, changes take place in Croatian trade as well. An example of this is the fact that, before the economic crisis, Croatian trade recorded high growth rates, but the share of trade in GDP dropped from $10.9 \%$ in 2007 to $9.9 \%$ in 2011. In the period from 2008 to 2011, there was a decline in the number of employees in trade. For example, in 2012, compared to 2009, employment in trade decreased by $10.7 \%$ (Pupavac, 2014). When it comes to sale, its level decreased by $19 \%$, compared to 2008 , as a result of lower demand during recession. 


\section{COMPETITIVE MARKET ENVIRONMENT}

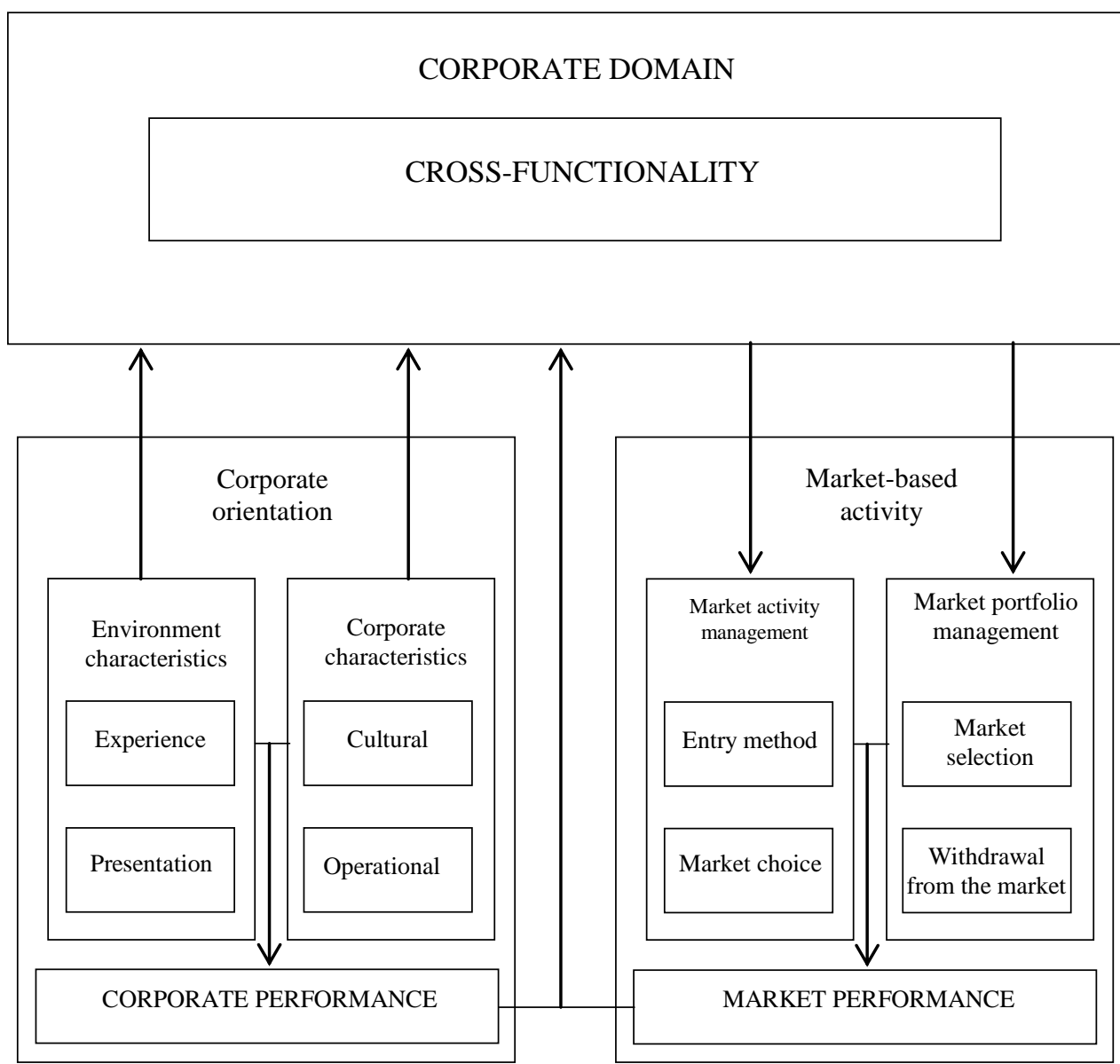

Fig. 1 Structure of internationalization of trade: study of operational activities and environment

Adapted from: Alexander, N. \& Doherty, A.M.(2010), International retail research: focus, methodology and conceptual development, International Journal of Retail \& Distribution Management, 38(11/12), 928-942.

The importance of trade and retail sector in the overall Croatian economy is confirmed by figures such as the share of trade entrepreneurs in the total number, number of employees in trade in the total number, as well as gross fixed capital formation. The analysis of relevant statistics (Osnovni pokazatelji trgovine u Republici Hrvatskoj u 2013, 2014) shows that trade has a leading role in the economy of the Republic of Croatia. Thus, in 2013, a total of 101.191 entrepreneurs operated in Croatia, of which 26.342 entrepreneurs in trade, which means that the share of trade amounted to 26.03\% (Bačelić Grgić, 2014).

Judging by investment, Croatian trade also recorded positive results. Croatian National Bank data shows that, in the period from 1993 to 2013, amount of foreign investment in the 
Republic of Croatia totaled 28.86 billion euros, with the amount of this investment in the retail sector being 3.98 billion euros (Priopćenje inozemna izravna ulaganja u Republiku Hrvatsku po djelatnostima, 2013). Of this, investment in wholesale sector and trade mediation was 2.64 billion euros, and in retail trade and repair sector 1.34 billion euros.

As already stated, Croatian trade has a significant share in the total number of employees. Trade is the second largest employer in the country today, after manufacturing industry (Bačelić Grgić, 2014). Thus, the trade sector employs $15.80 \%$ of all employees, with trade being the largest generator of new jobs as well.

Preliminary data shows gradual convergence of trends in Croatian trade to trade trends in the European Union. In such an environment, the process of internationalization of trade and retail on the Croatian market takes place, which has been rising in intensity since 1999 and still does (Knežević \& Szarucki, 2011). Revitalization of the Croatian trade sector began in 1997, when construction of a flexible legal framework started, as an additional incentive to the development of trade (Knego \& Knežević, 2010; Knežević, 2003; Knežević, 2007; Knežević et al., 2011). This created conditions for the entry of foreign capital onto the Croatian market. After that, a large number of European trade companies, driven by economic interests, entered the Croatian market. Mercatone (Italy), Billa (Austria), Metro (Germany), Ipercoop (Italy), Kaufland (Germany), and others opened their retail stores in all major Croatian cities (Zagreb, Split, Osijek, Rijeka, and others.). The biggest retail companies in Croatia, seen by sales volume in 2014, are presented in Table 1.

Table 1 Leading retail companies in Croatia (FMCG sector)

\begin{tabular}{|c|c|c|c|c|c|c|}
\hline Company & $\begin{array}{c}\text { Year of } \\
\text { establishment/ } \\
\text { entry onto the } \\
\text { Croatian market }\end{array}$ & $\begin{array}{l}\text { Registered office/ } \\
\text { ownership }\end{array}$ & $\begin{array}{l}\text { Number } \\
\text { of } \\
\text { branches }\end{array}$ & $\begin{array}{l}\text { Revenue in } \\
2013 \\
\text { (in millions } \\
\text { of kunas) }\end{array}$ & $\begin{array}{c}\text { Number of } \\
\text { countries where } \\
\text { the company } \\
\text { operates }\end{array}$ & $\begin{array}{l}\text { Revenue } \\
\text { in } 2013 \\
\text { in millions } \\
\text { of dollars }\end{array}$ \\
\hline Konzum & 1957 & $\begin{array}{c}\text { Zagreb/ } \\
\text { Konzum d.o.o. }\end{array}$ & 700 & 13.391 & 3 & 4.011 \\
\hline Plodine & 1993 & Rijeka/Plodine d.d. & 71 & 3.268 & 1 & 3.268 \\
\hline Lidl & $1973 / 2006$ & $\begin{array}{l}\text { Nekarsulm (Zagreb } \\
\text { for Croatia/Lidl d.o.o. }\end{array}$ & 80 & 3.004 & 26 & 98.662 \\
\hline Kaufland & $1984 / 2001$ & $\begin{array}{c}\text { Nekarsulm/German } \\
\text { Kaufland Stiftung \& Co. } \\
\text { KG (German Schwarz- } \\
\text { Beteiligungs-GmbH) }\end{array}$ & 28 & 2.721 & 26 & 98.662 \\
\hline Merkator & $1949 / 2000$ & $\begin{array}{c}\text { Ljubljana (Sesvete } \\
\text { for Croatia)/ } \\
\text { Mercator-H d.o.o. }\end{array}$ & 22 & 2.586 & 5 & - \\
\hline METRO & $1964 / 2001$ & Düsseldorf/Metro AG & 8 & $2.177 *$ & 32 & 86.393 \\
\hline Spar & $1932 / 2001$ & $\begin{array}{c}\text { Amsterdam (Zagreb for } \\
\text { Croatia)/SPAR } \\
\text { HRVATSKA d.o.o. }\end{array}$ & 22 & 2.028 & 8 & 11.411 \\
\hline Tommy & 1992 & Split/Tommy d.o.o. & 142 & 1.976 & 1 & 1.976 \\
\hline Billa & $1953 / 1999$ & $\begin{array}{c}\text { Wiener Neudorf (Zagreb } \\
\text { for Croatia/REWE } \\
\text { International AG }\end{array}$ & 57 & 1.624 & 11 & 51.109 \\
\hline
\end{tabular}

Source: Authors, based on http://business.hr/hr/Kompanije, Deloitte (2015), www.hsz.hr. 
The share of international retail companies, as well as their sales activity (in \%) on the Croatian market, can be seen in Graphs 1 and 2.

$\%$

80

70

60

50

40

30

20

10

0

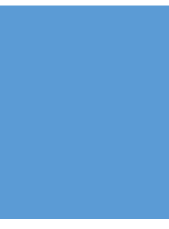

Croatian retail companies

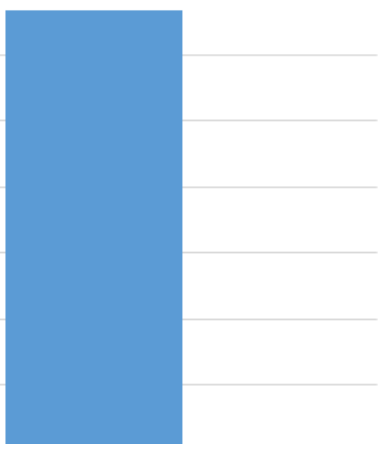

Foreign retail companies

Graph 1 Share of foreign companies' sales activity in total sales of retail companies (in FMCG sector) Source: Authors

3

2.5

1.5

0.5

0

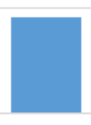

Lidl

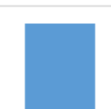

Kaufland

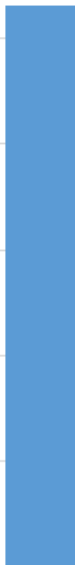

Spar

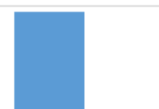

Billa

Graph 2 Share of foreign retail companies' sales activities on the Croatian market Source: Authors 
Analyzing the share of foreign and Croatian retail companies' sales activity in total sales of leading retail companies (Graph 1), one can see greater share of foreign (66.7), compared to Croatian (33.3) companies. This indicates high concentration of foreign retail companies, but also a high level of internationalization of trade on the Croatian market.

If one analyzes the percentage share of sales activities of foreign retail companies on the Croatian market in total volume of their sales, one can see that it ranges from 0.38 to $2.66 \%$. This leads to the conclusion that the Croatian market is relatively new for these companies, and that future expansion of their activities is to be expected. If one compares the analyzed foreign retail companies (Graph 2), it can be seen that SPAR has the biggest share, meaning that this company has the highest percentage share of sales activity (2.66) in the total sales volume on the Croatian market, compared to the other analyzed companies.

\section{INTERNATIONALIZATION OF RETAIL IN SERBIA}

Trade, including retail, occupies an important place in the overall economy of the Republic of Serbia, and has a key role in the creation of an integrated market economy. The importance of trade in the overall economy of the Republic of Serbia is illustrated by statistical data on its share in macroeconomic indicators (Graph 3), as well as data on the number of companies, employees, and number of retail stores (Tables 2, 3, and 4).

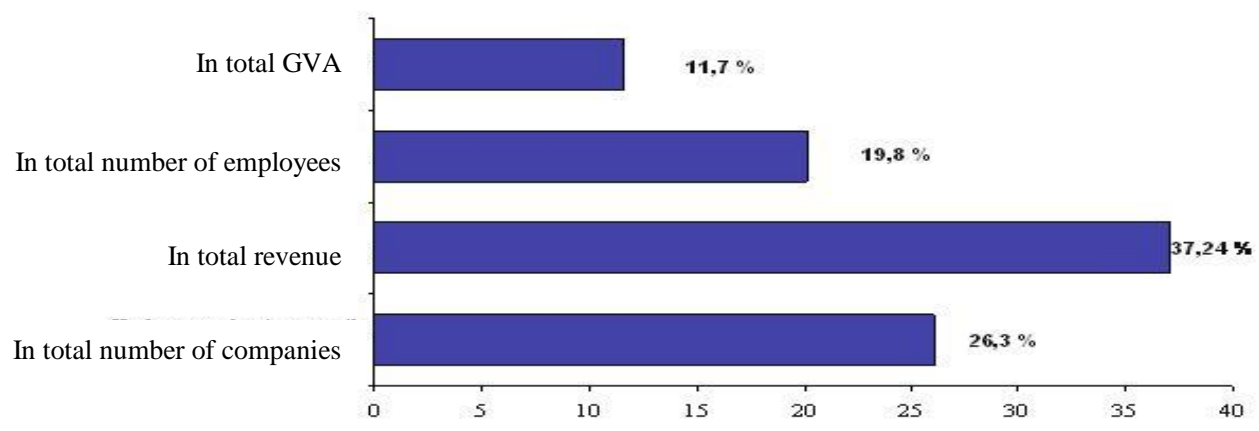

Graph 3 Share of trade in macroeconomic indicators of the Republic of Serbia (2014) Source: http://www.pks.rs/PrivredaSrbije.aspx $? \mathrm{id}=17 \& \mathrm{p}=2 \&$

Table 2 Number of companies in internal trade (2014)

\begin{tabular}{lrrrr}
\hline & Total trade & Retail & Wholesale & $\begin{array}{c}\text { Sales and repair } \\
\text { of motor vehicles }\end{array}$ \\
\hline Total enterprises and entrepreneurs & 44.385 & 14.313 & 25.755 & 4.317 \\
Enterprises & 34.708 & 6.112 & 25.102 & 3.494 \\
Entrepreneurs & 9.677 & 8.201 & 653 & 823 \\
\hline
\end{tabular}

Source: http://www.pks.rs/PrivredaSrbije.aspx $? \mathrm{id}=17 \& \mathrm{p}=2 \&$ 
Table 3 Number of employees in trade (2014)

\begin{tabular}{lcccc}
\hline & Total trade & Retail & Wholesale $\begin{array}{c}\text { Retail and } \\
\text { wholesale in } \\
\text { motor vehicles }\end{array}$ \\
\hline Total enterprises and entrepreneurs & 378.461 & 274.586 & 76.117 & 27.758 \\
Enterprises & 218.085 & 114.210 & 76.117 & 27.758 \\
Entrepreneurs & 160.375 & 160.376 & - & - \\
\hline \multicolumn{2}{c}{ Source http//www pks.rs/PrivredaSrbije aspx?id=17\&p=2\& }
\end{tabular}

Table 4 Number and size of stores

\begin{tabular}{|c|c|c|}
\hline & Number of stores & $\begin{array}{c}\text { Total size } \\
\text { (storage and sales space) } \\
{\text { in } \mathrm{m}^{2}}\end{array}$ \\
\hline Total enterprises and entrepreneurs & 114.253 & 11.101 .717 \\
\hline Enterprises & 42.339 & 9.291 .532 \\
\hline Entrepreneurs & 71.914 & 1.810 .185 \\
\hline
\end{tabular}

Source: http://www.pks.rs/PrivredaSrbije.aspx?id=17\&p=2\&

Serbian market in recent years has become attractive to a large number of international retail chains, which apply different strategies and models of business expansion (Ćuzović \& Sokolov Mladenović, 2015b; Ćuzović \& Sokolov Mladenović, 2015c). International retail chains continuously increase their market share and the number of stores. They are primarily concentrated in market areas of major cities, where they open large retail formats to attract consumers to make major purchases, but they also open smaller retail formats to meet the needs of consumers, who, in choosing stores, give priority to accessibility and comfort of rapid shopping. Lately, there are more and more rumors about their further expansion, as well as the potential arrival of new foreign retail chains.

Arrival of regional players inevitably affected the operations of national retail companies. Faced with new competition and new trends that foreign retail companies have brought to our market, local retailers adopt new business strategies, to survive on the market and improve competitive advantage. A large number of local companies have failed in this, so they are totally marginalized, with only few that survived or improved their position on the domestic market.

Thus, both domestic and foreign trade companies operate on our market. Applying a clearly defined strategy of creating and sustaining competitive advantage, they try to maximize their business results. Starting from the assumption that revenue is a measure of business performance of companies, Table 5 presents leading trading companies on the Serbian market in 2014.

The share of international retail companies, as well as their sales activity (in \%) on the Serbian market can be seen in Graphs 4 and 5. 
Table 5 Leading trading companies on the Serbian market (in FMCG sector)

\begin{tabular}{lclcccc}
\hline Company & $\begin{array}{c}\text { Year of } \\
\text { establishment } \\
\text { lentry onto the } \\
\text { Serbian market }\end{array}$ & $\begin{array}{c}\text { Registered } \\
\text { office/ } \\
\text { ownership }\end{array}$ & $\begin{array}{c}\text { Number } \\
\text { of } \\
\text { branches }\end{array}$ & $\begin{array}{c}\text { Revenue in 2013 } \\
\text { (in millions of } \\
\text { dinars) }\end{array}$ & $\begin{array}{c}\text { Number of } \\
\text { countries where } \\
\text { the company } \\
\text { operates }\end{array}$ & $\begin{array}{c}\text { Revenue } \\
\text { in 2013 } \\
\text { (in millions } \\
\text { of dollars) }\end{array}$ \\
\hline Delhaize Serbia & 2012 & Belgium & 381 & 101.624 .416 & 9 & 28.037 \\
Mercator-S & 2002 & Slovenia & 137 & 63.363 .962 & 5 & - \\
IDEA & 2005 & Croatia & 190 & 55.404 .705 & 3 & 4.011 \\
DIS & 1999 & Serbia & 16 & 25.413 .272 & 1 & - \\
Metro cash\&carry & 2005 & Germany & 9 & 17.494 .013 & 32 & 86.393 \\
UNIVER EXPORT & 1990 & Serbia & 42 & 13.791 .932 & 1 & - \\
Aman & 1992 & Serbia & 139 & 7.521 .939 & 1 & - \\
Gomex & 1995 & Serbia & 91 & 6.589 .587 & 1 & - \\
INTEREX & 2005 & France & 9 & 4.966 .353 & 6 & 37.351 \\
\hline
\end{tabular}

Source: Authors, based on Deloitte (2015), www.deloitte.com; www.apr.gov.rs.

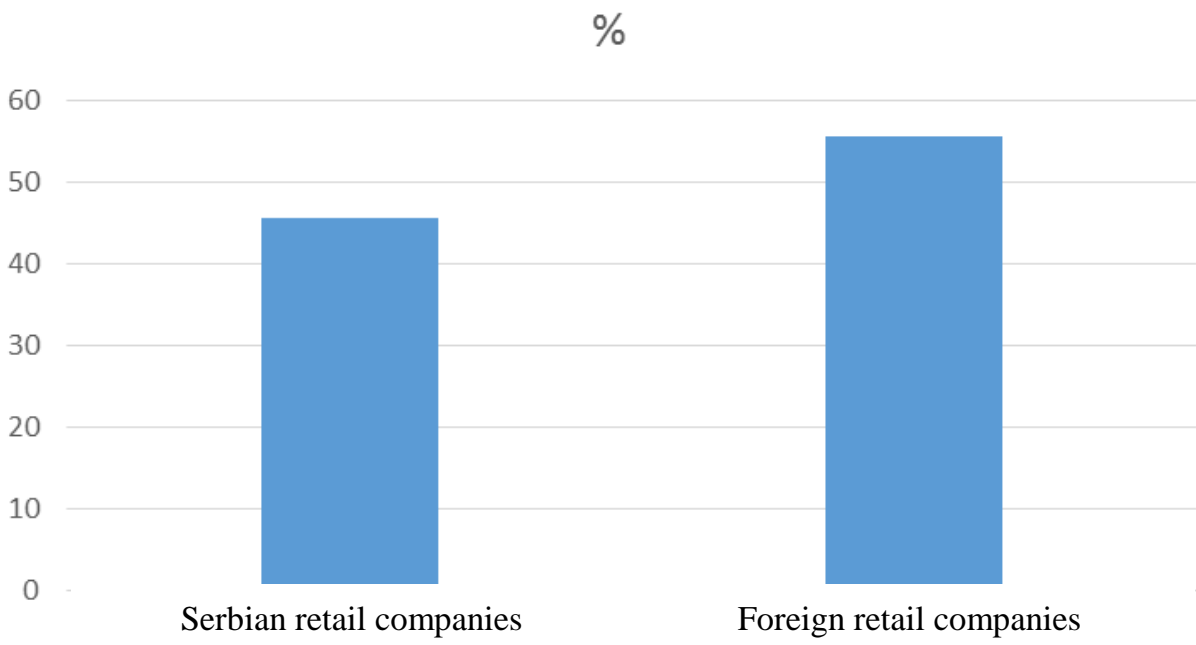

Graph 4 Share of foreign companies' sales activity in total sales of retail companies (in FMCG sector) Source: Authors

Analyzing the share of foreign and Serbian retail companies' sales in the total sales of leading retail companies (Graph 4), one can see greater share of foreign (55.5) in relation to Serbian companies (45.5). This indicates high concentration of foreign retail companies, as well as a high level of internationalization of trade on the Serbian market. 


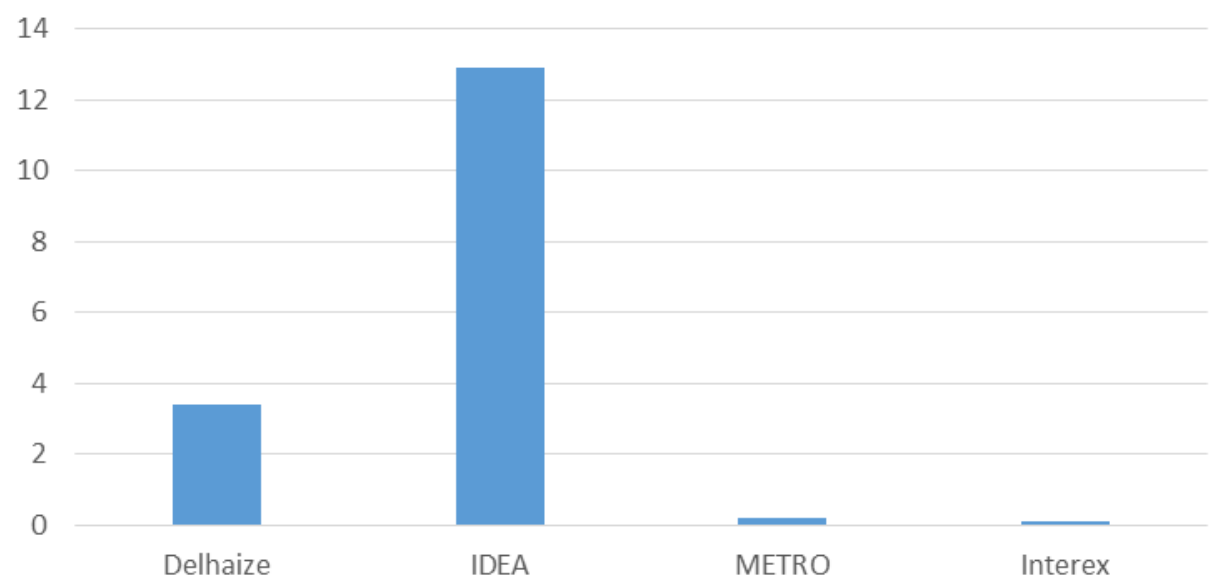

Graph 5 Share of sales activities on the Serbian market in the total sales volume of international retail chains Source: Authors

If one analyzes the percentage share of international trading companies' sales activities on the Serbian market in the total volume of their sales, it can be seen that it ranges from 0.12 to $12.9 \%$. This suggests that the Serbian market is relatively new for these companies, and that expansion of their activities can be expected in the future. If one compares the analyzed international trading companies (Graph 5), it is noticeable that IDEA has the biggest share, meaning that this company has the highest percentage share of sales activity in the total sales volume on the Serbian market, compared to the other analyzed companies.

\section{SIMILARITIES AND DIFFERENCES IN THE LEVEL OF INTERNATIONALIZATION IN CROATIA AND SERBIA - RECOMMENDATIONS FOR THE FUTURE}

Bearing in mind the previous analyses, as well as plenty of theoretical and practical studies on internationalization of trade, especially retail, in Croatia, it can be seen that during 2006 and 2007 Croatia was one of the most attractive markets in the region (Knežević \& Szarucki, 2011). When it comes to the Serbian market, the analysis shows that in 2005 and 2006 Serbia was one of the most attractive markets in the region. This, in turn, raises the issue of effects of internationalization of trade on Croatian and Serbian economies, as well as effects on customers, i.e. consumers. This issue was the subject of research of a large number of theorists and practitioners, trying to conduct an adequate cost-benefit analysis of international retail companies' operations on the Croatian market. Relying on Dawson's model (Dawson et al., 2003) of internationalization of trade, which observes effects of internationalization on the host country as one of its dimensions, as well as numerous studies of internationalization of retail on the Croatian market, the key effects of internationalization of trade on Croatian and Serbian economies are: 
- Changes in the structure and relationships in channels of distribution, as confirmed by cooperation among international retail companies and Croatian companies, on the one hand, and Serbian companies, on the other hand, in various segments;

- Increasing competition, as evidenced by intense activity of both Croatian and Serbian companies in the field of performing marketing functions;

- New ways of competitive behavior;

- Increasing investment, as evidenced by data on such trends in the Croatian trade sector, while such investment was less in Serbian trade;

- Restructuring of the sector; and

- Accelerated innovation, as evidenced by examples of trading companies' operations on Croatian and Serbian markets.

- From the standpoint of customers, i.e. consumers, effects of internationalization of trade and retail on Croatian and Serbian markets are the following:

- Increased awareness of consumers (better knowledge of products, prices, terms of sale), as confirmed by trading companies' operations aimed at permanent distribution of information on discount prices, products on sale, loyalty programs, and the like;

- Changes in consumption habits, as evidenced by research results about weekly or monthly shopping;

- Improved availability of products and services.

Taking into account these similarities, as well as indicators of the current state of the economy, especially in Croatian trade and retail, it can be seen that Croatia remains an attractive market and that one can expect a new wave of internationalization.

When it comes to trade and retail on the market of Serbia, it is evident that trade has predominantly local character, with a small number of retail companies with developed sales network in the narrow regional area within the national market. Retail stores are primarily concentrated in relatively larger cities and larger urban areas, where concentration of population and market potential are higher. These stores mostly use insufficiently developed technology, business strategies are focused on the local environment, and product range is dominated by products of local suppliers, whose brands are well-known to a consumer segment that gravitates to them.

A specific feature of the Serbian market is reflected in the existence of a large number of small retailers. Although under strong pressure from large retail chains, small retailers still have a significant share in the total turnover. However, lately there has been a trend of reduction of their market power in favor of an integrated retail. In order to survive on the market, small retailers often change the location of their retail stores, adapting to expansion of large stores. Although the number of existing independent retailers constantly decreases, new ones appear, who try to service the needs of narrow market segment from new locations.

In addition to weak purchasing power of the population and a decrease in retail sales, retail operators on the Serbian market face many other problems, which mainly arise from general characteristics of underdeveloped domestic market and overall economic situation. The current situation in the economy and trade of Serbia will mark future directions of internationalization of trade. In that regard, what encourages is the announced opening of the first department store of the Swedish company Ikea, as well as the first sales outlets of the German company Lidl. 


\section{CONCLUSION}

Today's trade, as well as retail, carries out its activities in conditions of intense market globalization. Market globalization brings internationalization of trade and retail. Due to saturation of domestic markets, large trade, i.e. retail chains direct their activities towards foreign markets. Numerous factors dictate their international activities. In fact, the current economic crisis has changed the direction of internationalization of trade and retail, so that the so-called emerging markets are becoming more and more attractive. Markets in former socialist countries are particularly interesting and attractive to large retail chains. Bearing in mind all these facts, the paper analyzed the achieved level of internationalization of retail on Croatian and Serbian markets. The aim of the study was to analyze market and trade characteristics in both countries, in order to determine the achieved level of internationalization of retail. Both markets have the same social and economic legacy, with Croatia being the member of the European Union, while Serbia is currently a signatory of the Stabilization and Association Agreement, oriented to full membership in the European Union. The analysis showed that the Croatian market has realized a higher level of internationalization of retail in relation to the market of Serbia, and that Croatia can expect a further wave of internationalization. What is more, Croatian positive experience can serve Serbia in tracing future directions of internationalization of retail and attracting further investment by leading retail chains.

Acknowledgement: The paper is a part of the research done within the project 179081, funded by the Ministry of Education, Science and Technological Development of the Republic of Serbia.

\section{REFERENCES}

Alexander, N. \& Doherty, A.M. (2009). International Retailing. New York: Oxfort University Press.

Alexander, N. \& Doherty, A.M. (2010). International retail research: focus, methodology and conceptual development. International Journal of Retail \& Distribution Management, 38(11/12), 928-942.

Alexander, N. \& Myers, H. (2000). The retail internationalization process. International Marketing Review, $17(4 / 5), 334-353$.

Alexander, N. (1989). The internal market of 1992: attitudes of leading retailers. Retail\&Distribution Management, 17(1), 13-15.

Alexander, N. (1990a), Retailers and international markets: motives for expansion. International Marketing Review, 7(4), 75-85.

Alexander, N. (1990b). Retailing post-1992. Service Industrial Journal, 10(2), 172-187.

Bačelić Grgić, I. (2014). Uloga trgovine u gospodarstvu Republike Hrvaske i gospodarstvu Europske unije-s posebnim osvrtom na zaposlene u djelatnostima trgovine [The Role of the Trade in Economy of Republic of Croatia and the EU with Particular Reference to the Employees in Trade]. Zbornik sa Medunarodne konferencije Perspektive trgovine 2014-Tehnologija, znanje, ljudi, Ekonomski fakultet, Zagreb, 98-114.

Ćuzović, S., Sokolov-Mladenović, S. (2008). Strategies entry of international retail companies on serbian market. International Conference Commerce in contemporary society: theory and practise, Varna, 10-11 October 2008, 313-324.

Ćuzović, S., Sokolov-Mladenović, S. (2015a). Menadžment internacionalizacije trgovine. [Management of the Internationalization of Trade]. Ekonomski fakultet, Niš.

Ćuzović, S., Sokolov Mladenović, S. (2015b). Faktori i modeli internacionalizacije trgovine-primer tržišta Republike Srbije [Factors and Models of the International of Trade - The Example of the Market of Republic of Serbia] . Međunarodni naučni skup Izazovi globalizacije u društveno-ekonomskom okruženju, Novo Mesto, 53-64 
Ćuzović, S., Sokolov Mladenović, S., Samardžija, J. (2015c). Strategije trgovinskog marketinga u uslovima internacionalizacije-primer tržišta Republike Srbije [Strategies of Trade Marketing in Terms of Internationalization - The Example of the Market of Republic of Serbia]. Međunarodni naučni skup SM2015, Palić, 691-702.

Deloitte (2015), www.deloitte.com; www.apr.gov.rs (accessed 20.09.2015.)

Doherty, A.M. (2000). Factors influencing international retailers' market entry, mode strategy: qualitative evidence from UK fashion sector. Journal of Marketing Management, 16(1/3), 223-245.

http://business.hr/hr/Kompanije, Deloitte (2015), www.hsz.hr (accessed 11.09.2016.)

http://www.hgk.hr/category/djelatnost/gosp_trgovina (accessed 15.09.2016.)

http://www.pks.rs/PrivredaSrbije.aspx?id=17\&p=2\& (accessed 15.09.2016.)

Knežević, B. \& Szarucki, M. (2011). Comparison of retail internationalization in Poland and Croatia. Zbornik sa Međunarodne konferencije Trgovina kao pokretač razvoja Srednje i Jugoistočne Evrope, Ekonomski fakultet, Zagreb, 175-189.

Knego, N., Knežević, B. (2010). Internationalization in the function of retail trade concentration in the Croatia in Kandzija, V. and Kumar, A. (eds.) Economic integrations, competition and cooperation, University of Rijeka, Faculty of Economics, 378-392.

Knežević, B. (2003) Globalization and Croatian selling industry. Proceedings of The Fifth International Conference on "Enterprise in Transition", 22-24th May, Tucepi, University of Split, Faculty of Economics Split, 226-237.

Knežević, B., (2007). Utjecaj znanja na stvaranje vrijednosti u trgovini [The Impact of Knowledge on Value Creation in Trade]. Sveučilište u Zagrebu Ekonomski fakultet Zagreb, doctoral thesis in Croatian.

Knežević, B., Renko, S., Knego, N., (2011). Changes in Retail industry in the EU. Business Management and Education, 9(1), 34-49.

Osnovni pokazatelji trgovine u Republici Hrvatskoj u 2013., 2014 [Basic Indicators of Trade in the Republic of Croatia in 2013, 2014]. Hrvatska gospodarska komora, Sektor za trgovinu, Zagreb, www.dsz.hr; www.mfin.hr (accessed 20.09.2016.)

Priopćenje inozemna izravna ulaganja u Republiku Hrvatsku po djelatnostima, 2013. [Press Release: Foreign Direct Investments in the Republic of Croatia by Secors, 2013], Hrvatska narodna banka, Zagreb.

Pupavac, D. (2014). Menadžment ljudskih potencijala u trgovini-troškovni ili razvojni pristup [Human Resources Management in Trade - Cost or Developmental Approach]. Zbornik sa Međunarodne konferencije Perspektive trgovine 2014-Tehnologija, znanje, ljudi, Ekonomski fakultet, Zagreb, 84-97.

Shulyn, T., \& Yazdanifard, R. (2015). Globalization of Retailing and Related Cross Cultural Issues. International Journal of Management, Accounting and Economics, 2(9), 1088-1109.

Sternquist, B. (1997). International expansion by US retailers. International Journal of Retailer \& Distribution Management, 25(8), 262-268.

Swoboda, B., Zentes, J. \& Elsner, S. (2009). Internationalisation of retail firms: state of the art after 20 years of resarch. Marketing Journal of Research and Management, 5(2), 105-126.

Dawon, J., Mukoyama, M., Chul Choi, S., Larke, R. (2003). Retail internationalisation in Asia, London: Routledge.

Vida, I. \& Fairhurst, A. (1998). International Expansion of retail firms: a theoretical approach for future investigations. Journal of Retailing and Consumer Services, 5(3), 143-151.

Williams, D. (1992a). Motives for retailer internationalization: their impacts, structure and implications. Journal of Marketing Management, 8, 269-285.

Williams, D. (1992b). Retailer internationalization: and empirical inquiry. European Journal of Marketing, 29, (8/9), 269-285.

Yeng, W. F., \& Yazdanifard, R. (2015). Opportunities and Challenges in the World of Retailing and the Importance of Adaption to the New Markets. International Journal of Management, Accounting and Economics, 2(9), 1110-1121. 


\section{INTERNACIONALIZACIJA MALOPRODAJE - KOMPARATIVNA ANALIZA HRVATSKE I SRBIJE}

Globalizacija i integracija svetskog tržišta za svoju posledicu ima internacionalizaciju maloprodaje $i$ ukupne trgovine. Krajem 20. i početkom 21. veka internacionalizacija postaje sveprisutna pojava odnosno fenomen u maloprodaji. Tako postaje permanentan i neminovan proces. Internacionalizacija trgovine, posebno maloprodaje, zahvata mnoge zemlje, s tim što se odvija različitim intenzitetom. Predmet istraživanja ovog rada jeste dostignuti nivo internacionalizacije trgovine, posebno maloprodaje, na tržištu Republike Hrvatske i Republike Srbije. Razlozi odabira upravo ovih zemalja su brojni. Jedan od njih jeste i činjenica da obe država potiču od bivše jugoslovenske federacije. S druge strane, Hrvatska je najnovija članica Evropske unije (od 1. jula 2013. godine), a Srbija je potpisala Sporazum o stabilizaciji i pridruživanju i nalazi se na putu otvaranja pregovora o članstvu. Iz ovih razloga, iskustvo Hrvatske može da posluži Srbiji kao orijentir u realizaciji aktivnosti iz segmenta trgovine $i$ njene internacionalizacije. Cilj rada jeste mapiranje aktivnosti Srbije u procesu dalje internacionalizacije maloprodaje.

Ključne reči: maloprodaja, internacionalizacija, tržište, Hrvatska, Srbija 